\title{
Perancangan Sistem Pengontrol Keamanan Rumah Dengan Smart CCTV Menggunakan Arduino Berbasis Telegram
}

\author{
Dedi Setiawan, Joni Eka Candra, Cosmas Eko Suharyanto
}

Program Studi Teknik Informatika, Universitas Putera Batam

\section{KEYWORDS}

Home Security, Cctv, Nodemcu Esp8266,

Vc0706, Telegram Messenger.

\section{CORRESPONDENCE}

E-mail: ddswawan@gmail.com

\section{PENDAHULUAN}

Kemanan bagian aspek penting didalam kehidupan sehari-hari, salah satunya pada keamanan rumah, karena rumah suatu kebutuhan pokok dalam kehidupan manusia dan tempat yang dipergunakan berlindung diri, istirahat memulihkan kondisi lelah fisik setelah bepergian ataupun setelah menjalankankan kegiatan sehari-hari. Maka rumah harusnya menjadi tempat yang aman, nyaman dan jauh dari segala jenis tindakan kejahatan. Suatu rumah dikatakan aman ketika rumah juga dalam keadaan kosong akan tetapi tidak terjadinya hal yang tidak kita inginkan seperti tindakan pencurian atau perampokan. Maraknya tindakan kejahatan menuntut untuk diciptakannya sesuatu security system yang bisa membantu kita untuk memantau dan mengawasi semua yang berharga milik kita, salah satu alat yang bisa dipakai untuk keperluan tersebut ialah kamera CCTV (Closed Circuit Television). Perangkat CCTV yang bisa mengirimkan video signal atau audio ke tempat tertentu yang bertujuan untuk memastikan keamanan area/lokasi ataupun tempat tertentu.

Menggunakan kamera pengawas di setiap sudut rumah, seperti di teras, ruang tamu dan bagasi guna untuk keamanan disaat kita sedang beraktifitas diluar rumah atau rumah dalam keadaan kosong. Namun kamera pengawas hanya berfungsi sebagai pengintai atau merekam situasi pada saat itu saja. Sehingga, ketika adanya hal-hal yang mencurigakan pada saat rumah kita tinggalkan dalam keadaan kosong kita tidak tahu dan tidak dapat melakukan tindakan untuk mencegah kejadian yang tidak di inginkan.

Arduino adalah proyek open sources juga merupakan platform komputasi fisik yang berbasis pada mikrokontroler, platform ini banyak dipergunakan dan sudah diketahui oleh banyak orang. Sehingga muncul Arduino IDE sebagai dasar bahasa pemrograman untuk memproses dan memprogram mikrokontroler.

Telegram Messenger merupakan alat yang dipergunakan untuk saling berkomunikasi, bertukar pesan, dan bisa berfungsi untuk mengirim gambar, pesan suara, file document. Aplikasi Telegram Messenger dapat juga dihubungkan dengan Arduino, dengan system bot yang tersedia untuk fungsikan sebagai alat pengontrol atau perintah.

Dengan sebuah alat smart CCTV menggunakan Arduino bisa meminimkan tindakan pencurian ataupun perampokan karena kamera akan mengirimkan pesan gambar kepemilik rumah kemudian dengan aplikasi Telegram Messenger pemilik rumah dapat mengaktifkan alarm peringatan yang sudah dipasang dirumah tersebut. Alarm juga dapat berfungsi secara otomatis apabila sensor mendeteksi adanya gerakan, dan pesan juga akan dikirimkan kepemilik rumah bahwa alarm sedang aktif dan disaat yang bersamaan kamera akan mengambil gambar kemudian mengirimkan pesan gambar kepemilik rumah.

\section{METODOLOGI PENELITIAN}

Waktu proses penelitian yang berlangsung dimulai dari bulan maret 2019 sampai bulan juli 2019, dimulai dari konsultasi judul 
sampai pada proses penyusunan skripsi, lokasi penelitian ini dilakukan di Perum Galaxy Park Marina, Tj Riau, Sekupang Batam, Kepulauan Riau.

Tahap penelitian merupakan langkah-langkah yang harus di lakukan didalam melaksanakan penelitian, dari prosses pertama hingga proses paling akhir. Setiap langkah dalam penelitian harus dijelaskan supaya memperoleh pengetahuan yang dapat menyelesaikan suatu masalah yang akan dihadapi dipenelitian ini kedepannya, upaya langkah-langkah ini bisa dilakukan secara ilmiah, sistemati, dan logis, ditahap penelitian bisa juga diartikan dengan design penelitian, bertujuan untuk membantu dan membentuk jalur suatu penelitian sehingga bisa diperoleh suatu logika didalam pengujian hipotesis ataupun didalam pembuatan suatu kesimpulan.

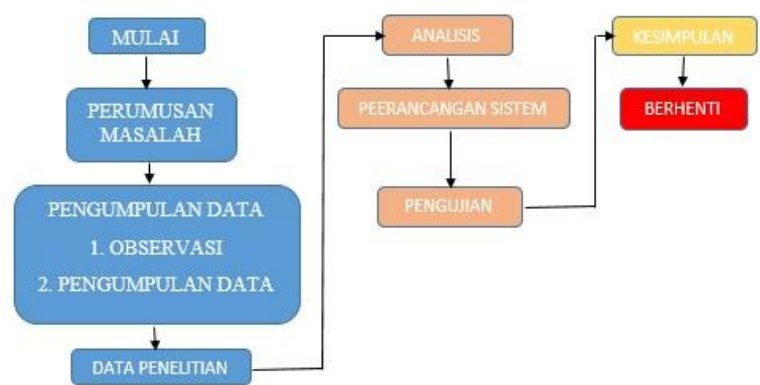

Gambar 1 Desain Tahapan Penelitian

Pada gambar diatas bisa dijelaskan sebagai berikut:

Tahap Awal

Langkah pertama didalam pelaksanaan penelitian ini ialah dengan melakukan study pustaka untuk memperoleh informasi mengenai klasifikasi suatu masalah yang terjadi tentang Sistem Keamanan Rumah di Perum Galaxy Park Marina, kemudian melakukan sebuah pendataan tentang tingkatan kesulitan masalah, sesudah memperoleh data, tahapan berikutnya melakukan suatu analisa.

\section{Tahap Analisis}

Langkah berikutnya yaitu masuk proses tahapan analisa, ditahap ini akan dilakukan proses analisa untuk menentukan metode penelitian didalam memecahkan permasalah yang akan diselesaikan, dari hasil data yang telah terukmpul supaya bisa merancang suatu sistem atau alat yang akan di mulai dari perancangan mekanik, elektric sampai dengan tahap desain produk yang akan dibuat serta dikembangkan, setelah selesai dirancang proses selanjutnya ialah melakukan pengujian pada sistem atau alat yang sudah dibuat, supaya dapat mengetahui tingkat keberhasilan pada pembuatan sistem atau alat.

\section{Kesimpulan}

Setelah dilakukannya proses analisis hingga tahapan pengujian, langkah berikutnya ialah, menarik suatu kesimpulan dari hasil pengujian yang sudah dilakukan supaya dapat meyelesaikan permasalahan hasil dari observasi yang sudah dilakukan.

\section{Perancangan Alat}

\section{Perancangan Perangkat keras (Hardware)}

Perancangan hardware, ialah suatu bagian sangat penting untuk proses perancangan alat, dan nantinya berguna untuk sebagai panduan atau ilustrasi sebelum keproses berikutnya yaitu proses membuat alat, ada beberapa perancangan yang diterapkan sebelum membuat alat, antara lain adalah:

\section{Perancangan Mekanik}

Perancangan mekanik ialah suatu desain alat yang akan di jadikan sebagai panduan atau gambaran bentuk jadi alat yang akan dibuat, perancangan mekanik juga merupakan desain untuk protoype yang akan dibuat untuk lebih mudah mengetahui bentuk hasil dari perancangan mekanik dapat dilihat pada gambar berikut ini:

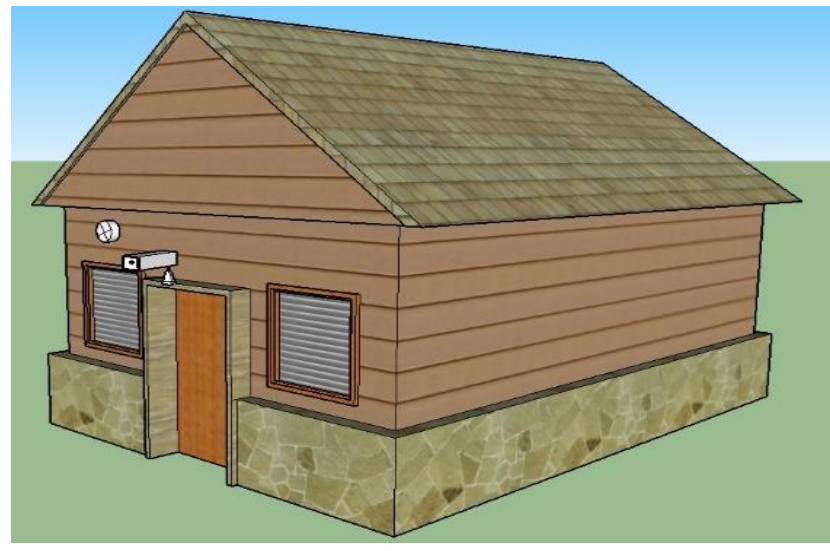

Gambar 2 Desain Ilustrasi dan Peletakan Kamera dan Sensor

Pada gambar 2 diatas merupakan ilustrasi peletakan dari kamera dan sensor ketika nantinya alat smart CCTV diterapkan pada rumah, kamera diletakkan diatas pintu supaya dapat mengambil gambar obyek dengan jelas ketika sensor mendeteksi adanya pergerakan, dan dapat memantau keseluruh teras rumah.

\section{Perancangan Elektrik}

Perancangan elektrik merupakan rancangan software yang di gunakan saat membuat alat, berupa system design dari tiap komponen elektronic yang di pakai untuk panduan dalam merancang suatu alat. Untuk penjelasan lebih lanjut, penulis dapat menjelaskannya dengan desain perancangan system dari komponen pada alat smart CCTV menggunakan Arduino ini yang didesain sedimikian rupa dengan memakai fritzing, aplikasi ini dapat dipakai untuk menggambar skematik bentuk dari rangkain elektornika yang telah disesain sesuai dengan kebutuhan. Berikut adalah beberapa design dari system hardware elektronik alat smart CCTV mengguakan Arduino ini dapat dilihat pada gambargambar yang ada dibawah ini:

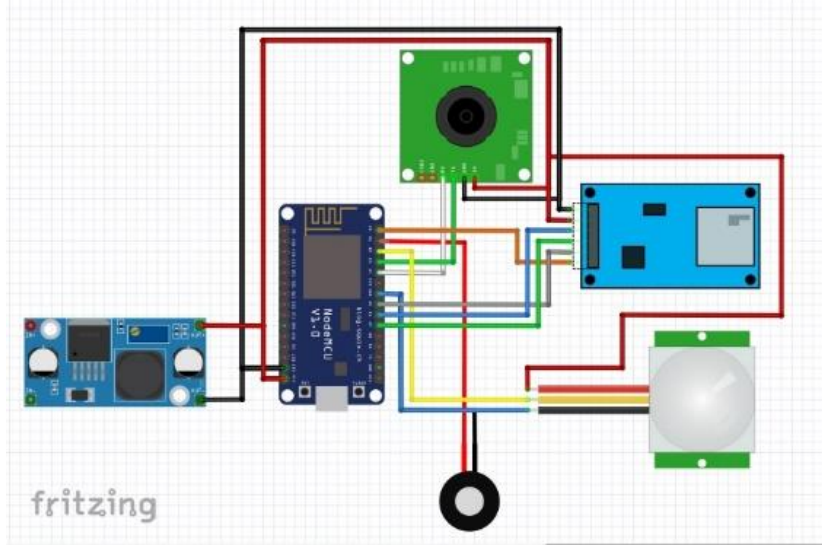

Gambar 3 Desain Hardware Elektronik pada Alat Smart CCTV Menggunakan Arduino 


\section{Perancangan Perangkat Lunak (Software)}

Perancangan software sebagai alat pengontrol yang bisa menghubungkan setiap komponen yang sudah terhubungkan secara langsung melalui instruksi program perintah, kemudian dipindahkan kepemroses utama supaya dapat dijalankan. Selanjutnya system dari perangkat lunak ini akan mengatur dan menjalankan fungsi dari kamera VC0706 dan sensor PIR guna untuk mendeteksi gerakan dan mengirimkan informasi ke aplikasi Telegram, setelah gambar terkirim buzzer bisa di aktifkan secara manual.

Pada saat menghidupkan alat, maka smart CCTV menggunakan Arduino akan mulai membaca koding pertama yaitu menghubungkan dengan wifi yang sudah ditentukan, kemudian berikutnya sensor akan mencoba membaca lokasi jika terdeteksi pergerakan maka buzzer akan berbunyi dan kamera akan menfoto lokasi. Perintah lainnya yaitu perintah untuk menfoto secara manual dan foto yang berhasil diambil akan dikirimkan ke aplikasi Telegram.

Untuk melihat urutan cara kerja suluruhnya pada system ini dapat di gambarkan dengan flowchart seperti contoh dibawah ini.

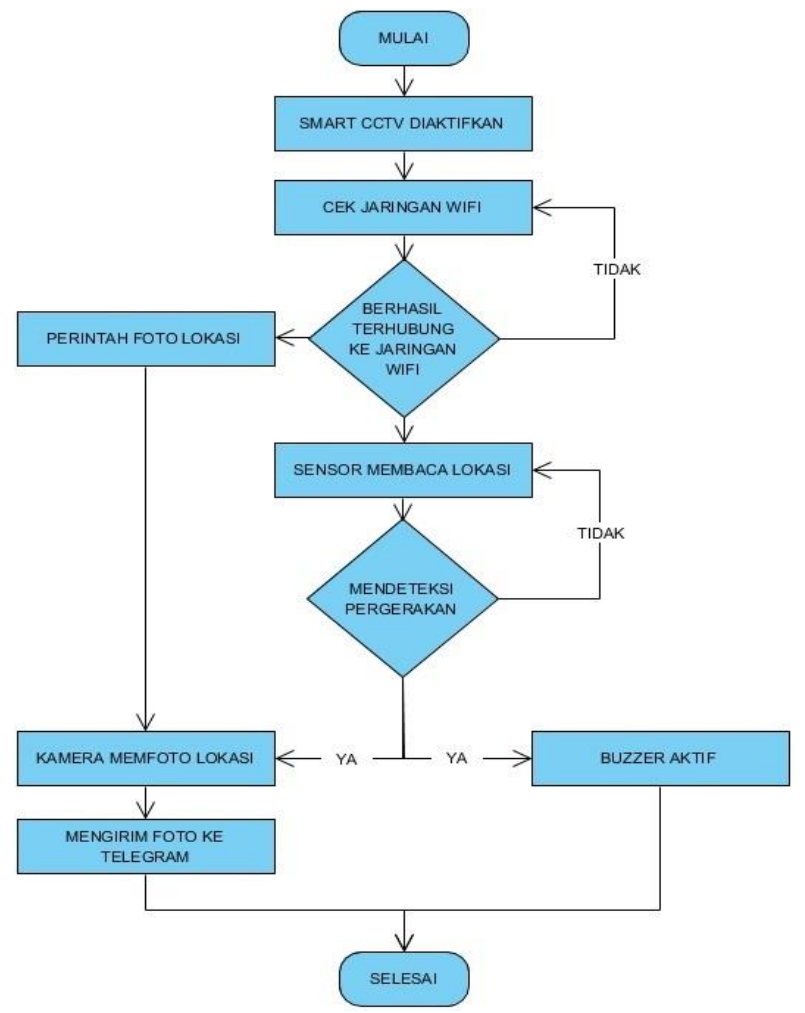

Gambar 4 Diagram flowchart

\section{HASIL DAN PEMBAHASAN \\ Hasil Perancangan Perangkat Keras}

Perancangan alat keras merupakan suatu proses untuk penerapan perancangan prototype suatu alat ataupun product. Pada pembuatan Smart CCTV menggunakan Arduino ini mempunyai beberapa contoh hardware yang sudah dirancang sedemikian rupa supaya dapat

bekerja sesuai tujuan yang diinginkan, untuk gambar dari perangat keras dapat dilihat pada gambar 5 yang ada dibawah ini.

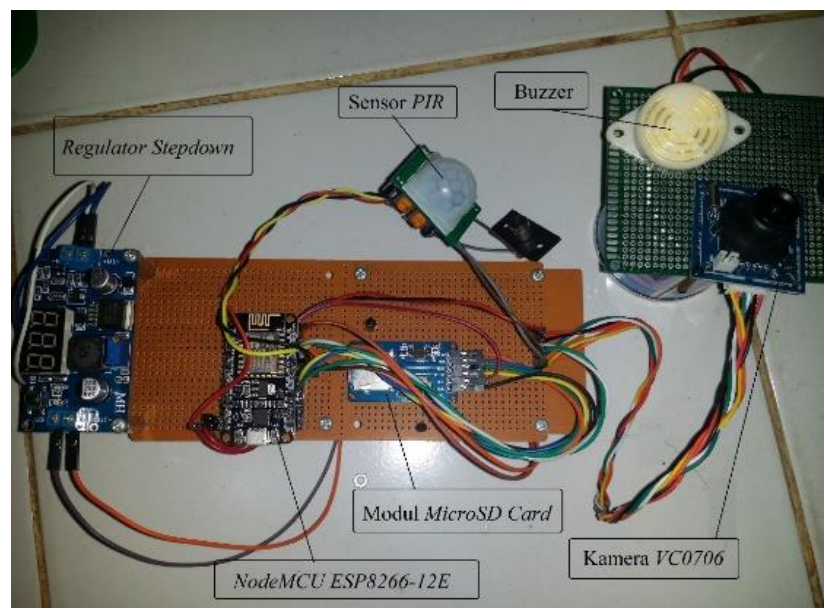

Gambar 5 Komponen alat smart CCTV sebelum disusun menjadi sebuah prototype

Gambar 5 diatas merupakan tampilan sebelum komponen diterapkan atau dirancang menjadi sebuah prototype, fungsi masing-masing komponennya dapat dijelaskan pada daftar tabel 1 nama komponen dan fungsi komponen.

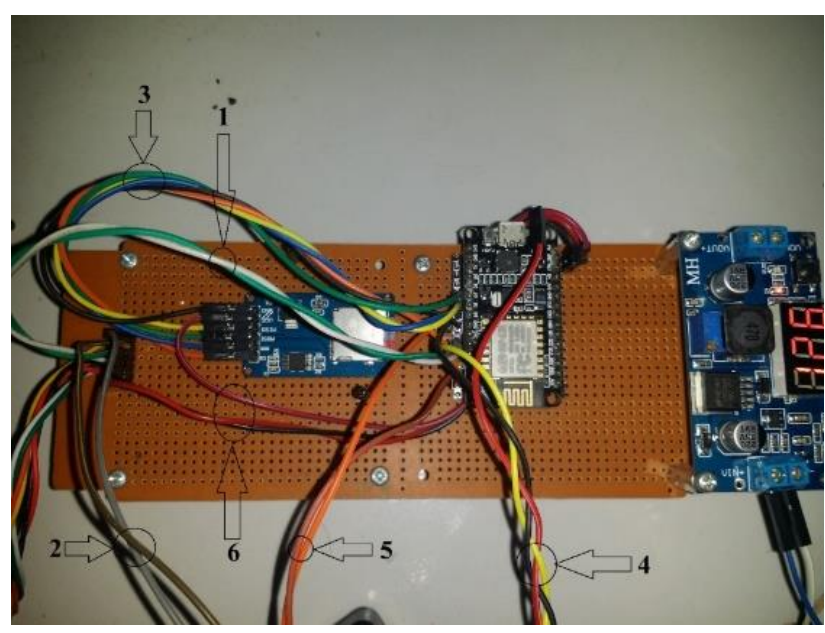

Gambar 6 Tampilan Depan Rangkaian yang Sudah Saling Terhubung

Pada gambar rangkaian diatas, dapat di jelaskan bahwa kabel tersebut dipakai untuk menyambungkan pin-pin dari setiap komponen ke NodeMCU ESP8266-12E yang berfungsi sebagai mikrokontroller. Supaya bisa mengetahui penyambungan jalur pin-pin tersebut dapat di jelaskan pada tabel 2 fungsi kabel penghubung pada setiap komponen. 


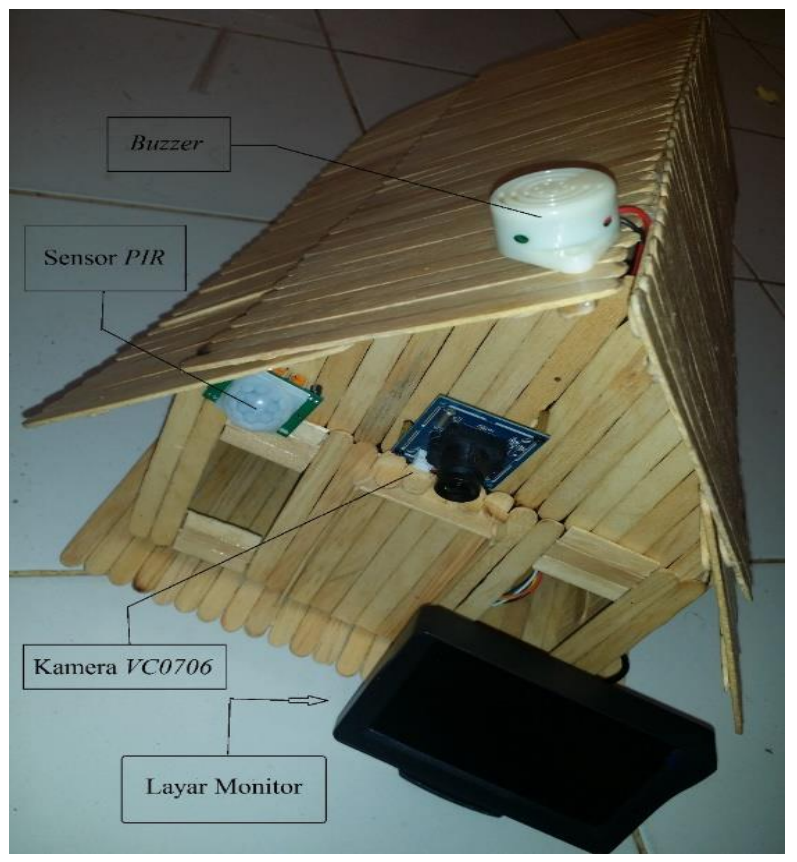

Gambar 7 Hasil Kontruksi atau Prototype alat Smart CCTV Menggunakan Arduino

Pada gambar 7 prototype diatas merupakan susunan atau tata letak komponen-komponen alat smart CCTV menggunakan Arduino, dimana kamera VC0706 terletak diatas pintu agar pengambilan gambar dapat mencangkup seluruh ruangan teras dan sensor PIR terletak disamping kanan dari kamera, buzzer terletak di atap kanan sebagai alarm, kemudian terdapat layar monitor sebagai pemantau dari hasil output video yang ditangkap oleh kamera.

\section{Hasil Pengujian Alat}

Pengujian alat dengan aplikasi Telegram untuk mengontrol alat smart CCTV menggunakan Arduino bertujuan untuk menguji respon alat smart CCTV menggunakan Arduino seperti buzzer, kamera, dan cek lokasi yang diperintah dari aplikasi Telegram yang diperintahkan dengan jarak jauh, dan lama waktu dari proses tiap responnya, dimana jika kurang dari 5 detik maka proses tergolong cepat, rentang 6-10 detik maka normal, dan jika lebih dari 10 detik maka respon tergolong lama. Hasil uji alat dapat dilihat pada tabel 4 dan tabel 5 .

Tabel 1 Nama Komponen dan Fungsi Komponen

\begin{tabular}{ll}
\hline \multicolumn{1}{c}{ Nama Rangkaian } & \multicolumn{1}{c}{ Fungsi Rangkaian } \\
\hline NodeMCU ESP8266- & $\begin{array}{l}\text { Sebagai Micro Controller dan } \\
\text { untuk menerima jaringan WiFi, } \\
\text { mengontrol semua komponen } \\
\text { yang terhubung }\end{array}$ \\
Sebagai perekam video dan \\
pengambilan gambar \\
Tempat untuk MicroSD Card \\
Modul MicroSD & $\begin{array}{l}\text { untuk menyimpan hasil foto } \\
\text { Rerfungsi sebagai menurunkan } \\
\text { arus Input maksimal 220 Volt } \\
\text { menjadi arus Output 5 Volt } \\
\text { Buzzer berfungsi sebagai output } \\
\text { suara dan sensor PIR sebagai } \\
\text { pendeteksi gerakan }\end{array}$ \\
\hline
\end{tabular}

Tabel 2 Fungsi Kabel Penghubung pada Setiap Komponen

\begin{tabular}{|c|c|c|}
\hline $\begin{array}{l}\text { Nomor } \\
\text { Pin }\end{array}$ & $\begin{array}{l}\text { Warna } \\
\text { Kabel }\end{array}$ & Pin Terhubung \\
\hline \multirow[t]{2}{*}{ Nomor 1} & Hijau & Pin TX VC0706 ke Pin D3 NodeMCU \\
\hline & Putih & Pin RX VC0706 ke Pin D2 NodeMCU \\
\hline \multirow[t]{2}{*}{ Nomor 2} & Oranye & Pin GND VC0706 ke Pin (-) RCA Socket \\
\hline & Kuning & Pin Video VC0706 ke Pin (+) RCA Socket \\
\hline \multirow[t]{5}{*}{ Nomor 3} & Hitam & $\begin{array}{l}\text { Pin GND Modul SDCard ke Pin GND } \\
\text { NodeMCU }\end{array}$ \\
\hline & Kuning & $\begin{array}{l}\text { Pin MISO Modul SDCard ke Pin D6 } \\
\text { NodeMCU }\end{array}$ \\
\hline & Hijau & $\begin{array}{l}\text { Pin MOSI Modul SDCard ke Pin D7 } \\
\text { NodeMCU }\end{array}$ \\
\hline & Biru & Pin SCK Modul SDCard ke Pin D5 NodeMCU \\
\hline & Oranye & Pin CS Modul SDCard ke Pin DO NodeMCU \\
\hline \multirow[t]{3}{*}{ Nomor 4} & Kuning & Pin Output PIR ke Pin D2 NodeMCU \\
\hline & Hitam & Pin (-) PIR ke Pin GND NodeMCU \\
\hline & Merah & Pin (+) PIR ke Pin Vin NodeMCU \\
\hline \multirow[t]{2}{*}{ Nomor 5} & Oranye & Pin (-) Buzzer ke Pin GND NodeMCU \\
\hline & Merah & Pin (+) Buzzer ke Pin D1 NodeMCU \\
\hline \multirow[t]{3}{*}{ Nomor 6} & Merah & Pin Vcc VC0706 ke Pin Vin NodeMCU \\
\hline & Merah & Pin Vcc Modul SDCard ke Pin Vin NodeMCU \\
\hline & Hitam & Pin GND VC0706 ke Pin GND NodeMCU \\
\hline \multirow[t]{2}{*}{ Nomor 7} & Merah & Pin (+) VOut Regulator ke Pin Vin NodeMCU \\
\hline & Hitam & Pin (-) VOut Regulator ke Pin GND NodeMCU \\
\hline \multirow[t]{2}{*}{ Nomor 8} & Merah & $\begin{array}{l}\text { Pin (+) Socket Adaptor ke Pin (+) } \\
\text { VInRegulator }\end{array}$ \\
\hline & Hitam & Pin (-) Socket Adaptor ke Pin (-) Vin Regulator \\
\hline
\end{tabular}

Tabel 3 Bagian dan Fungsi Alat Pada Prototype

\begin{tabular}{|c|c|}
\hline $\begin{array}{c}\text { Nama } \\
\text { Rangkaian/Alat }\end{array}$ & Fungsi \\
\hline Kamera $V C 0706$ & Untuk mengambil gambar dan video \\
\hline Sensor PIR & Untuk Mendeteksi Gerak \\
\hline Buzzer & Untuk menghasilkan Suara (Alarm) \\
\hline Layar Monitor & $\begin{array}{l}\text { Untuk menampilkan output video dari } \\
\text { kamera }\end{array}$ \\
\hline
\end{tabular}

Tabel 4 Data Hasil Pengujian Alat

\begin{tabular}{|c|c|c|c|c|c|c|c|c|c|c|}
\hline \multirow{3}{*}{$\begin{array}{l}\text { Peng } \\
\text { ujian }\end{array}$} & \multirow{3}{*}{$\begin{array}{c}\text { Jara } \\
\mathrm{k} \\
\text { (me } \\
\text { ter) }\end{array}$} & \multicolumn{9}{|c|}{ Proses Respon Alat Smart CCTV } \\
\hline & & \multicolumn{3}{|c|}{ Foto Lokasi } & \multicolumn{3}{|c|}{ Buzzer } & \multicolumn{3}{|c|}{ Cek Lokasi } \\
\hline & & $\begin{array}{l}\mathrm{Ce} \\
\text { pat }\end{array}$ & $\begin{array}{l}\text { Nor } \\
\text { mal }\end{array}$ & $\begin{array}{l}\mathrm{La} \\
\mathrm{ma} \\
\end{array}$ & $\begin{array}{l}\mathrm{Ce} \\
\text { pat }\end{array}$ & $\begin{array}{l}\text { Nor } \\
\text { mal }\end{array}$ & $\begin{array}{l}\mathrm{La} \\
\mathrm{ma} \\
\end{array}$ & $\begin{array}{l}\mathrm{Ce} \\
\text { pat }\end{array}$ & $\begin{array}{l}\text { Nor } \\
\text { mal }\end{array}$ & $\begin{array}{l}\mathrm{La} \\
\mathrm{ma} \\
\end{array}$ \\
\hline 1 & 1 & - & - & $\mathrm{Ya}$ & Ya & - & - & $\mathrm{Ya}$ & - & - \\
\hline 2 & 2 & - & - & Ya & Ya & - & - & Ya & - & - \\
\hline 3 & 3 & - & - & $\mathrm{Ya}$ & Ya & - & - & $\mathrm{Ya}$ & - & - \\
\hline 4 & 4 & - & - & $\mathrm{Ya}$ & $\mathrm{Ya}$ & - & - & $\mathrm{Ya}$ & - & - \\
\hline 5 & 5 & - & - & $\mathrm{Ya}$ & Ya & - & - & $\mathrm{Ya}$ & - & - \\
\hline 6 & 6 & - & - & $\mathrm{Ya}$ & $\mathrm{Ya}$ & - & - & $\mathrm{Ya}$ & & - \\
\hline 7 & 7 & - & - & $\mathrm{Ya}$ & $\mathrm{Ya}$ & - & - & $\mathrm{Ya}$ & - & - \\
\hline 8 & 8 & - & - & $\mathrm{Ya}$ & $\mathrm{Ya}$ & - & - & $\mathrm{Ya}$ & - & - \\
\hline 9 & 9 & - & - & $\mathrm{Ya}$ & $\mathrm{Ya}$ & - & - & $\mathrm{Ya}$ & - & - \\
\hline 10 & 10 & - & - & $\mathrm{Ya}$ & $\mathrm{Ya}$ & - & - & $\mathrm{Ya}$ & - & - \\
\hline
\end{tabular}


Dari data percobaan respon dari alat smart CCTV menggunakan Arduino dapat dihitung persentase tingkat keberhasilannya yaitu:

Tingkat keberhasilan

$=\frac{\text { Berhasil }}{\text { Percobaan }} \times 100 \%$

$=\frac{10}{10 \text { Percobaan }} \times 100 \%=100 \%$

Tabel 5 Data Hasil Pengujian Respon Alat

\begin{tabular}{|c|c|c|c|}
\hline \multirow{2}{*}{$\begin{array}{c}\text { Jarak } \\
\text { Pengujian }\end{array}$} & \multicolumn{3}{|c|}{$\begin{array}{c}\text { Respon Balasan ke Aplikasi Telegram dalam satuan } \\
\text { (detik) }\end{array}$} \\
\hline & Sensor PIR & Buzer & $\begin{array}{l}\text { Camera } \\
\text { VC0706 }\end{array}$ \\
\hline 1 Meter & 2-3 detik & $\begin{array}{c}2-3 \\
\text { detik }\end{array}$ & $\begin{array}{c}\text { 35-50 } \\
\text { detik }\end{array}$ \\
\hline 5 Meter & 2-3 detik & $\begin{array}{c}2-3 \\
\text { detik }\end{array}$ & $\begin{array}{l}35-50 \\
\text { detik }\end{array}$ \\
\hline 10 Meter & 2-3 detik & $\begin{array}{c}2-3 \\
\text { detik }\end{array}$ & $\begin{array}{l}35-50 \\
\text { detik }\end{array}$ \\
\hline
\end{tabular}

Hasil perhitungan diatas merupakan keberhasilan respon dari tiap-tiap fungsi rangkaian dari alat smart CCTV menggunakan Arduino yang diperintahkan melalui aplikasi Telegram yaitu kamera, buzzer dan, sensor. Ketiga rangkaian tersebut semua berfungsi namun hanya terdapat permasalahan di lama waktu proses pada kamera, karena prosesnya yang lama disaat penyimpanan hasil foto kedalam kartu memori sebelum mengirimkannya ke aplikasi Telegram.

Pada tabel diatas dapat dijelaskan bahwa jarak tidaklah berpengaruh terhadap lama respon tiap komponen, tetapi yang berpengaruh adalah baik buruknya jaringan internet. Karena selama aplikasi Telegram sebagai pengontrol dan NodeMCU ESP8266-12E sebagai pemrosesnya sama-sama terhubung dengan jaringan internet maka alat smart CCTV menggunakan Arduino akan bekerja dengan normal, baik buruknya jaringan internet itulah yang mempengaruhi lamanya respon atau proses pengiriman data.

\section{KESIMPULAN DAN SARAN}

Berdasarkan dari hasil penelitian dan pengujian yang sudah dilakukan, dapat disimpulkan hasil perancangan alat smart CCTV menggunakan Arduino ini dapat berfungsi sebagai alat untuk sistem keamanan rumah, dimana saat rumah dalam keadaan kosong maka sensor akan selalu aktif untuk mendeteksi disektiaran lokasi, dan jika terdapat gerakan disekitaran lokasi maka sensor akan mendeteksi kemudian kamera akan memfoto dan mengirimkannya ke aplikasi Telegram, dengan ini jika adanya upaya tindakan kejahatan maka kita dapat mencegahnya dengan mengaktifkan alarm yang dapat dihidupkan melalui aplikasi Telegram dimanapun kita berada selama terhubung dengan jaringan internet.Dengan alat smart CCTV menggunakan Arduino rumah akan mudah di pantau dimanapun kita berada, sehingga kita bisa merasanyaman ketika ruma dalam keadaan kosong saat kita bepergian.

\section{DAFTAR PUSTAKA}

[1] Akanksha Singh, Pal, A., \& Rai, B. (2015). GSM Based Home Automation, Safety and Security System Using Android Mobile Phone. International Journal of Engineering Research And, V4(05), 490-494. https://doi.org/10.17577/ijertv4is050648.

[2] Annapurna, L., Mounika, K., Chary, K., \& Afroz, R. (2015). Smart Security System using Arduino and Wireless Communication. International Journal of Engineering Innovation \& Research, 4(2), 326-331.Retrieved from www.irjet.net.

[3] Atmoko, Eko Hari. 2012. Membuat Sendiri CCTV Berkelas Enterprise Dengan Biaya Murah. Yogyakarta: C.V ANDI OFFSET.

[4] Fatoni, A., Nugroho, D. D., \& Irawan, A. (2015). Rancang Bangun Alat Pembelajaran Microcontroller. Jurnal PROSISKO, Vol. 2 No.(1), 10-18.

[5] Kurniawan, M. I., Sunarya, U., \& Tulloh, R. (2018). Internet of Things: Sistem Keamanan Rumah berbasis Raspberry Pi dan Telegram Messenger. ELKOMIKA: Jurnal Teknik Energi Elektrik, Teknik Telekomunikasi, \& Teknik Elektronika,6(1), https://doi.org/10.26760/elkomika.v6i1.1

[6] Maiyana, E. (2018). Pemanfaatan Android Dalam Perancangan Aplikasi Kumpulan Doa. Jurnal Sains Dan Informatika, 4(1), 5465.https://doi.org/10.22216/jsi.v4i1.3409.

[7] Musrifah, A., \& Mutia, E. (2017). Pembuatan Aplikasi Pengelolaan Proposal Di Unit Kegiatan Pengelola ( Upk ) Kecamatan Mande Berbasis. Media Jurnal Informatika, 9(1), 28-36.Retrieved from http://jurnal.unsur.ac.id/mjinformatika\%0Ap-issn.

[8] Rifa'i, A. F. (2016). Sistem Pendeteksi Dan Monitoring Kebocoran Gas ( Liquefied Petrolum Gas ) Berbasis Internet of. Teknik Informatika UIN Sunan Kalijaga Yogyakarta Jalan Marsda Adisucipto Yogyakarta, 1(1), 513.Retrieved from digilib.uin-suka.ac.id/22442/1/10902106-1-PB.pdf

[9] Risanty, R. D., \& Arianto, L. (2015). Rancang Bangun Sistem Pengendalian Listrik Ruangan Dengan Menggunakan Atmega 328 Dan Sms Gateway Sebagai Media Informasi. Jurnal Sistem Informasi, 7(2), 1-10

[10] Siswanto, Anif, M., Nurhayati, D., \& Yuhefizar. (2017). Pengamanan Pintu Ruangan Menggunakan Arduino Mega 2560, MQ-2, DHT-11 Berbasis Android. JURNAL RESTI, 1(1), 19-25.

[11] Wahyudin, Wahyudi, S., \& Robbi, M. I. A. (2015). Visualisasi Masjid Agung Rangkasbitung Berbasis 3D Dengan Menggunakan Google Sketchup dan After Effect. Jurnal Pengembangan Riset Dan Observasi Sistem Komputer, Vol. 2(2), Hal 63-64.

[12] Samanta, S., Khan, K. K., Bhattacharyya, A., Das, S., Barman, A., Mathur, M. K., \& University. (2016). Home automation using arduino WiFi module ESP8266. m(9), 1446-1456 .Retrieved from.http:// aiktcdspace.org:8080/jspui/handle/ 123456789/1558 
[13] Ridwan, M., \& Santoso, K. A. (2019). Sistem Pengamanan Rumah Berbasis Sms Dan Kamera Vc0706 Dengan Menggunakan Mikrokontroler Arduino Uno. JKTE UTA’45 JAKARTA, 3(1), 3143. Retrievedfromhttp: //journal.uta45jakarta.ac.id/ index.php/JKTE/article/view/1185

[12] Sumajouw, D. F., MT, M. E. I. N. ST., \& Sompie, S. R. U. A. (2015) Perancangan Sistem Keamanan Rumah Tinggal Terkendali Jarak Jauh. Perancangan Sistem Keamanan Rumah Tinggal Terkendali Jarak Jauh, 3(2301), 44-53. Retrieved from https://ejournal.unsrat.ac.id /index.php/elekdankom/article /view/8249 